\title{
Single and multi-gene phylogeny of Hepatospora (Microsporidia) - a generalist pathogen of farmed and wild crustacean hosts
}

\author{
K. S. BATEMAN ${ }^{1}$, D. WIREDU-BOAKYE ${ }^{2}$, R. KERR ${ }^{1}$, B. A. P. WILLIAMS ${ }^{2}$ and \\ G. D. STENTIFORD ${ }^{1}$ \\ ${ }^{1}$ European Union Reference Laboratory for Crustacean Diseases, Centre for Environment, Fisheries and Aquaculture \\ Science (Cefas), Weymouth Laboratory, Weymouth, Dorset, DT4 8UB, UK \\ ${ }^{2}$ Biosciences, University of Exeter, Geoffrey Pope Building, Stocker Road, Devon, EX4 4EU, UK
}

(Received 3 December 2015; revised 12 February 2016; accepted 23 February 2016; first published online 22 March 2016)

\begin{abstract}
SUMMARY
Almost half of all known microsporidian taxa infect aquatic animals. Of these, many cause disease in arthropods. Hepatospora, a recently erected genus, infects epithelial cells of the hepatopancreas of wild and farmed decapod crustaceans. We isolated Hepatospora spp. from three different crustacean hosts, inhabiting different habitats and niches; marine edible crab (Cancer pagurus), estuarine and freshwater Chinese mitten crab (Eriocheir sinensis) and the marine mussel symbiont pea crab (Pinnotheres pisum). Isolates were initially compared using histology and electron microscopy revealing variation in size, polar filament arrangement and nuclear development. However, sequence analysis of the partial SSU rDNA gene could not distinguish between the isolates ( $\sim 99 \%$ similarity). In an attempt to resolve the relationship between Hepatospora isolated from E. sinensis and C.pagurus, six additional gene sequences were mined from on-going unpublished genome projects (RNA polymerase, arginyl tRNA synthetase, prolyl tRNA synthetase, chitin synthase, beta tubulin and heat shock protein 70). Primers were designed based on the above gene sequences to analyse Hepatospora isolated from pea crab. Despite application of gene sequences to concatenated phylogenies, we were unable to discriminate Hepatospora isolates obtained from these hosts and concluded that they likely represent a single species or, at least subspecies thereof. In this instance, concatenated phylogenetic analysis supported the SSU-based phylogeny, and further, demonstrated that microsporidian taxonomies based upon morphology alone are unreliable, even at the level of the species. Our data, together with description of H. eriocheir in Asian crab farms, reveal a preponderance for microvariants of this parasite to infect the gut of a wide array of decapods crustacean hosts and the potential for Hepatospora to exist as a cline across wide geographies and habitats.
\end{abstract}

Key words: edible crab, pea crab, Chinese mitten crab, microsporidian, Hepatospora, multi-gene phylogeny, taxonomy, Enterocytozoonidae.

\section{INTRODUCTION}

Microsporidia are single-celled eukaryotic intracellular parasites known to infect a range of vertebrate and invertebrate hosts (Mathis et al. 2005). Since the inception of the phylum 'Microsporidia', both phylogenetic placement of the group and classification within the group have proven problematic [reviewed in (Corradi and Keeling, 2009)]. Early phylogenies used to place microsporidia within the tree of life failed to account for rate heterogeneity among gene sites, base-compositional biases and the overall accelerated evolutionary rate characteristic of microsporidian genomes (Hirt et al. 1999) and thus microsporidia were for a long-time considered basal eukaryotes. They are now, along with the Cryptomycota, considered the most basal fungi

* Corresponding author: European Union Reference Laboratory for Crustacean Diseases, Centre for Environment, Fisheries and Aquaculture Science (Cefas), Weymouth Laboratory, Weymouth, Dorset DT4 8UB, UK. E-mail: kelly.bateman@cefas.co.uk group, a new classification based on the phylogenetic analysis of 200 genes (James et al. 2013).

Within the phylum, in the past, classification of taxa has been based on structural characteristics, ultrastructural morphology and karyotypic evidence (Canning, 1953; Vavra and Undeen, 1970; Shadduck et al. 1990; Cali et al. 1993). Now there is a compounding body of evidence supporting the idea that morphological and developmental features in this phylum are plastic between both closely and distantly related microsporidia (Vossbrinck and Debrunner-Vossbrinck, 2005; Stentiford et al. 2013). Stentiford et al. (2013) observed that microsporidians isolated from marine decapod crustaceans that would have been classed as distantly related taxa (Nadelspora and Ameson) under a morphology-based classification system are in fact close relatives on rDNA-based phylogenetic trees and are potential life-cycle variants of the same taxon. An example of a highly plastic morphological character used in classification is nuclear configuration. Two configurations are known to exist in microsporidia: a 
monokaryon (an individual nucleus) and a diplokaryon (two apposed nuclei). Whilst some species retain the same nuclear configuration throughout their life cycle, others switch between the nuclear stages depending upon life-cycle stage, and polymorphic species shift between the nuclear stages when changing hosts or tissues (Vávra and Larsson, 2014).

For many years the alternative to morphological characters has been the SSU rRNA gene, which has now been amplified and sequenced from over 1000 species of microsporidia. However, the rDNA sequences amplified are generally only able to resolve taxonomic relationships down to the genus level (Vossbrinck et al. 1998; Vossbrinck and Debrunner-Vossbrinck, 2005). The most commonly used primers, F18 and 1492R (Vossbrinck et al. 1993; Kent et al. 1996) amplify a 1400 bp fragment of the most conserved region of the SSU rDNA and omit the internal transcribed spacer (ITS) (Vossbrinck and Debrunner-Vossbrinck, 2005), a region reported to be highly variable even within species and hence highly informative for intraspecies differentiation analyses (Gresoviac et al. 2000; Sak et al. 2011). However, even if this region was commonly amplified for microsporidia, there are other issues with using $\mathrm{SSU}$ as a marker for closely related species. In at least some microsporidia, the process of concerted evolution that typically keeps rDNA copies uniform within the genome, does not seem to be present. For example, Ironside (2013), O'Mahony et al. (2007) and Tay et al. (2005) observed a higher ITS sequence variation between repeats in the same genome than between different genomes for some Nosema species, which means that caution needs to be used when employing rDNA to discriminate between closely related microsporidia.

One of the issues emerging from the difficulty in resolving close phylogenetic relationships and morphological plasticity in microsporidians is the assignment of appropriate species names. This is an important issue because taxonomic names of pathogenic species are fed into legislative frameworks that are used to inform policy making (Stentiford et al. 2014). Therefore there is a growing need to find alternative molecular markers to resolve questions in microsporidia taxonomy. There is currently wholegenome data for 20 microsporidian species on the publicly available MicrosporidiaDB database. With cheaper thorough-put sequencing technologies and the advent of single cell genome sequencing, we can only expect this number to increase. This provides a minable resource for molecular characters for multi-locus phylogenies (Capella-gutiérrez et al. 2012).

We isolated putative Hepatospora sp. parasites from three different crustacean hosts, inhabiting different habitats and niches; marine edible crab (Cancer pagurus), estuarine and freshwater Chinese mitten crab (Eriocheir sinensis) and the marine mussel symbiont pea crab (Pinnotheres pisum). Isolates were initially compared using histology and electron microscopy revealing not only a similar life cycle, but also the variation in size, polar filament arrangement and nuclear development (Table 1). However, sequence analysis of the partial SSU rDNA gene could not distinguish between the isolates $(\approx 99 \%$ similarity). Here we take advantage of the current microsporidian whole-genome database and our in-house genomic data to construct a six-gene concatenated phylogenetic tree for Hepatospora eriocheir, a parasite of the invasive Chinese mitten crab (Stentiford et al. 2011), a pea crab (P. pisum) infecting microsporidium (Longshaw et al. 2012) and a novel microsporidium that infects commercially important edible crabs (C. pagurus), all from European waters. Our results revealed that Hepatospora isolates from the three different crustacean hosts are likely to be microvariants of a single species. Further, they support the concept that microsporidian taxonomies based upon morphology are not only unreliable, but can also be deceptive, even at the level of the species. Our data, together with description of H. eriocheir as an agent of emergent disease in Asian crab aquaculture (Ding et al. 2016) reveal a preponderance for microvariants of $H$. eriocheir to infect the gut of a wide array of decapods crustacean hosts across wide geographic boundaries and in a range of habitats.

\section{MATERIALS AND METHODS}

Eriocheir sinensis, Cancer pagurus and Pinnotheres pisum sampling

Chinese mitten crabs (E. sinensis) were sampled from two locations in the Thames Estuary; a site near to the Millennium Dome (51:27:12N, 00-00-44E) and another at Tilbury Power Station (51:27:12N, 0023-10E). Crabs were collected using Fyke nets and from the screens of water intake pipes at the power station. Edible crabs (C. pagurus) were captured using baited pots in the Weymouth and Portland area of the English Channel, UK $\left(50^{\circ} 32^{\prime} 50^{\prime \prime} \mathrm{N}\right.$, $002^{\circ} 11^{\prime} 00^{\prime \prime} \mathrm{W}$ ) as previously described (Bateman et al. 2011). Live crabs were transported to the Cefas laboratory in Weymouth and anaesthetized by chilling on ice for $30 \mathrm{~min}$ before dissection. The hepatopancreas, gill, gonad, central nerve ganglia, heart and body muscle was removed from the crabs and fixed in Davidson's sea water fixative for histology. Additional hepatopancreas samples were fixed in $2.5 \%$ glutaraldehyde in $0.1 \mathrm{M}$ sodium cacodylate buffer for electron microscopy, and 100\% ethanol and frozen, for molecular analyses.

For P. pisum sampling, blue mussels (Mytilus edulis) were collected from a range of sites around the UK. Mussels were opened by cutting the 
Table 1. Comparison of host and structure [histological, electron microscopy and molecular data (SSU 18s rRNA)] from the Hepatospora isolates

\begin{tabular}{|c|c|c|c|}
\hline \multicolumn{4}{|l|}{ Host } \\
\hline Species & Pinnotheres pisum & Eriocheir sinensis & Cancer pagurus \\
\hline Family & Pinnotheridae & Varunidae & Cancridae \\
\hline Habitat & Symbiont of marine mussels & Estuarine & Marine \\
\hline \multicolumn{4}{|l|}{ Microsporidian } \\
\hline \multicolumn{4}{|l|}{ Pathology } \\
\hline Tissue & Hepatopancreas & Hepatopancreas & Hepatopancreas \\
\hline Site of development & $\begin{array}{l}\text { Cytoplasm of hepatopancrea- } \\
\text { tic epithelial cells }\end{array}$ & $\begin{array}{l}\text { Cytoplasm of hepatopancrea- } \\
\text { tic epithelial cells }\end{array}$ & $\begin{array}{l}\text { Cytoplasm of hepatopancrea- } \\
\text { tic epithelial cells }\end{array}$ \\
\hline \multicolumn{4}{|l|}{ Ultrastructure } \\
\hline Spore & Ellipsoid & Ellipsoid & Ellipsoid \\
\hline Size & $1.9 \times 0.9 \mu \mathrm{m}$ & $1.8 \times 0.9 \mu \mathrm{m}$ & $1.8 \times 0.9 \mu \mathrm{m}$ \\
\hline Polar filament & Isofilar & Isofilar & Isofilar \\
\hline Polar filament turns & $\begin{array}{l}5-6 \text { polar filament coils in a } \\
\text { single rank }\end{array}$ & $\begin{array}{l}\text { 7-8 polar filament coils in a } \\
\text { single rank }\end{array}$ & $\begin{array}{l}\text { 7-8 polar filament coils in a } \\
\text { single rank }\end{array}$ \\
\hline Nuclear status of spore & Diplokaryotic & Unikaryotic & Diplokaryotic \\
\hline Development & $\begin{array}{l}\text { Syncronous development } \\
\text { within a parasitophorous } \\
\text { vacuole }\end{array}$ & $\begin{array}{l}\text { Syncronous development } \\
\text { within a parasitophorous } \\
\text { vacuole }\end{array}$ & $\begin{array}{l}\text { Syncronous development } \\
\text { within a parasitophorous } \\
\text { vacuole }\end{array}$ \\
\hline \multicolumn{4}{|l|}{ Molecular analysis } \\
\hline GenBank Accession & - & HE $584635 \cdot 1$ & HE $584633 \cdot 1$ \\
\hline $\begin{array}{l}\text { SSU similarity } \\
\text { between isolates }\end{array}$ & $99 \%$ & $100 \%$ & $100 \%$ \\
\hline
\end{tabular}

abductor muscle and separating the valves. Symbiotic pea crabs ( $P$. pisum) found habituating the mantle of the host mussel were removed and anaesthetized on ice prior to bilateral dissection and removal of the hepatopancreas. Small portions of the organ were fixed in Davidson's sea water fixative, $2 \cdot 5 \%$ glutaraldehyde in $0 \cdot 1 \mathrm{M}$ sodium cacodylate buffer and 100\% ethanol for histology, electron microscopy and molecular techniques, respectively.

\section{Histology and transmission electron microscopy}

For histology, fixation was allowed to proceed for 24 $\mathrm{h}$ before samples were transferred to $70 \%$ industrial methylated spirit. Fixed samples were processed to wax in a vacuum infiltration processor using standard protocols. Sections were cut at a thickness of $3-5 \mu \mathrm{m}$ on a rotary microtome and mounted onto glass slides before staining with haematoxylin and eosin $(\mathrm{H} \& \mathrm{E})$ and Feulgen stains. Stained sections were analysed by light microscopy (Nikon Eclipse E800) and digital images and measurements were taken using the LuciaTM Screen Measurement System (Nikon, UK). For electron microscopy, tissues were fixed in $2 \cdot 5 \%$ glutaraldehyde in $0 \cdot 1 \mathrm{M}$ sodium cacodylate buffer ( $\mathrm{pH} 7 \cdot 4)$ for $2 \mathrm{~h}$ at room temperature and rinsed in $0 \cdot 1 \mathrm{M}$ sodium cacodylate

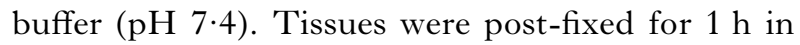
$1 \%$ osmium tetroxide in $0 \cdot 1 \mathrm{M}$ sodium cacodylate buffer. Samples were washed in three changes of $0 \cdot 1 \mathrm{M}$ sodium cacodylate buffer before dehydration through a graded acetone series. Samples were embedded in Agar 100 epoxy (Agar Scientific, Agar 100 pre-mix kit medium) and polymerized overnight at $60^{\circ} \mathrm{C}$ in an oven. Semi-thin $(1-2 \mu \mathrm{m})$ sections were stained with Toluidine Blue for viewing with a light microscope to identify suitable target areas. Ultrathin sections $(70-90 \mathrm{~nm})$ of these areas were mounted on uncoated copper grids and stained with $2 \%$ aqueous uranyl acetate and Reynolds' lead citrate (Reynolds, 1963). Grids were examined using a JEOL JEM 1400 transmission electron microscope and digital images captured using an AMT XR80 camera and AMTv602 software.

\section{Spore isolation and DNA extraction}

Hepatopancreas samples from histologically confirmed microsporidian-infected crabs were crushed with a sterile pestle and mortar in PBS. The homogenous mash was filtered through a 100 
$\mu \mathrm{m}$ mesh followed by cell sieving through $40 \mu \mathrm{m}$ filter. Filtrate was topped up to $50 \mathrm{~mL}$ using PBS/ triton-X $(0 \cdot 1 \%)$ and pelleted at $3220 \mathrm{~g}$ in an Eppendorf centrifuge precooled at $4{ }^{\circ} \mathrm{C}$, for 10 min. The supernatant was removed and the pellet (containing host cell debris and microsporidian spores) was resuspended in $2.5 \mathrm{~mL}$ of ice-cold water. Homogenate was added to the top of a Percoll density gradient and centrifuged at $1000 \mathrm{~g}$ in a pre-cooled centrifuge for $45 \mathrm{~min}$. Phase contrast and fluorescence microscopy were used to visualize the spores and to examine for purity following Percoll gradient purification. Spores were stained with the chitin marker calcoflour white (Darken, 1962).

For extraction of DNA, spores of the Pea crab and Mitten crab parasites were diluted 1 in $10(\mathrm{w} / \mathrm{v})$ in G2 buffer and Proteinase $\mathrm{K}$ was added at a concentration of $2 \mathrm{mg} \mathrm{mL}^{-1}$ (Qiagen, UK). The spores were subsequently disrupted in a Matrix D FastPrep cell disrupter (FastPrep, UK) by shaking on a homogenizer for $2 \mathrm{~min}$ at highest setting. Homogenized samples were incubated for $4 \mathrm{~h}$ at $56^{\circ} \mathrm{C}$. Total DNA was extracted using an EZ1 DNA tissue kit and EZ1 Advanced XL BioRobot (Qiagen) following manufacturers' instructions. For the edible crab parasite, aliquots of purified spores suspended in $1 \times$ PBS were mixed with liquid nitrogen in a sterile mortar. The mixture was slowly stirred until it solidified, after which it was ground with a sterile pestle for $10 \mathrm{~min}$. Liquid nitrogen was again added to the powder and the mix was ground for an additional $10 \mathrm{~min}$. This step was repeated three times before dissolving the resulting powder in $800 \mu \mathrm{L}$ of phenol ( $\mathrm{pH} 8 \cdot 0$ ). The homogenate was transferred to an Eppendorf tube and mixed by inversion and subsequently centrifuged for $10 \mathrm{~min}$ at $10000 \times \boldsymbol{g}$. The recovered supernatant was mixed by inversion with $400 \mu \mathrm{L}$ of chloroform and centrifuged for another $10 \mathrm{~min}$ at $10000 \times \boldsymbol{g}$. Genomic DNA was precipitated from the aqueous solution using a standard ethanol precipitation protocol (Ausubel et al. 2002) and sent to the University of Exeter sequencing service, UK for library preparation and Illumina sequencing.

\section{Identification of six marker genes from unpublished genome projects of $\mathrm{H}$. eriocheir and the edible crab microsporidian}

Orthologues of the six marker genes [amino acyl tRNA synthetases (Brown and Doolittle, 1999): arginyl tRNA synthetase and prolyl tRNA synthetase, beta-tubulin (Edlind et al. 1994), chitin synthase (Hinkle et al. 1997), heat shock protein 70 (HSP70) (Hirt et al. 1997) and RNA polymerase II (Hirt et al. 1999)] for publicly available microsporidian genomes were obtained from the MicrosporidiaDB database (Aurrecoechea et al. 2011) by initially performing word searches for the individual marker gene names for Encephalitozoon cuniculi GB-M1 and then using the 'transform by orthology tool' to find orthologues for all the other microsporidians in the database. To identify the desired marker genes in the newly sequenced genomes of $H$. eriocheir and the edible crab microsporidian, predicted open reading frames (ORFs) were queried using the microsporidian proteins obtained from MicrosporidiaDB (Aurrecoechea et al. 2011) using command line blastn (Mount, 2007) with an e-value cutoff of 1e-5. The top ORF hits were selected as the orthologous genes and orthology was verified by assessment of phylogenies of single genes.

Primer design, PCR and sequencing of the six-marker gene from the pea crab parasite

Due to the small amount of pea crab parasite genomic DNA recovered from the extraction procedure, gene-specific PCRs and subsequent sequencing was performed to retrieve the corresponding sequences for the six genes of the pea crab parasite rather than full genome sequencing. We designed gene-specific primers by using the first and last 18 nucleotides of the selected orthologues from $H$. eriocheir. A two-step nested PCR was done to amplify longer genes such as Arginyl tRNA and RNA polymerase (Table 2).

\section{Ribosomal DNA phylogenetic analyses}

Universal primers were used to amplify rDNA regions from genomic material extracted from $H$. eriocheir, pea crab and edible crab parasites (Table 3). The sequencing results for the PCR products were subsequently aligned and used to construct a neighbour-joining tree with MEGA software (Tamura et al. 2011). All PCR reactions were performed in a $50 \mu \mathrm{L}$ reaction mix consisting of $1 \times$ Green Go Taq buffer, $2.5 \mathrm{~mm} \mathrm{MgCl}_{2}, 0 \cdot 25$ mM dNTPs, $100 \mathrm{pM}$ each of the forward and reverse primer sets, 0.25 units Go Taq Flexi (Promega, UK) and $2 \cdot 5 \mu \mathrm{L}$ of extracted genomic DNA. Amplifications were performed on a Peltier PTC-225 thermal cycler with the following settings: Initialization step at $94^{\circ} \mathrm{C}$ for $5 \mathrm{~min}, 40$ cycles of 1 min denaturation at $95^{\circ} \mathrm{C}$, a $1 \mathrm{~min}$ annealing step (see Tables 1 and 2 for temperatures) and a 1 min extension step at $72{ }^{\circ} \mathrm{C}$. A final elongation step was carried out for $10 \mathrm{~min}$ at $72{ }^{\circ} \mathrm{C}$. Amplification products were resolved on $2 \%$ agarose gels stained with ethidium bromide and visualized using a UV illuminator.

Correct size products (Tables 2 and 3) were excised from the gels and purified using the Wizard SV gel and PCR purification system (Promega, UK). PCR products were sequenced using Sanger technology, ABI PRISIM Big Dye 
Table 2. Gene-specific primers were designed using the first and last 18 nucleotides of the selected orthologues from $H$. eriocheir

\begin{tabular}{|c|c|c|c|c|}
\hline Gene & $\begin{array}{l}\text { Primers } \\
\text { second } \\
\text { round }\end{array}$ & Sequence & $\begin{array}{l}\text { Annealing } \\
\text { temp }\left({ }^{\circ} \mathrm{C}\right)\end{array}$ & $\begin{array}{l}\text { Size of product } \\
\text { (bp in Mitten } \\
\text { crab) }\end{array}$ \\
\hline $\begin{array}{l}\text { Beta tubulin first } \\
\text { round }\end{array}$ & $\begin{array}{l}\mathrm{F} 1 \\
\mathrm{R} 1(\mathrm{R} \& \mathrm{C})\end{array}$ & $\begin{array}{l}\text { GTAAGTGATACAGTTGTAGAACC } \\
\text { CCTTCACCAGTGTACCAGTG }\end{array}$ & 55 & 683 \\
\hline $\begin{array}{l}\text { Beta tubulin second } \\
\text { round }\end{array}$ & $\begin{array}{l}\text { F1 } \\
\text { R2 }(\mathrm{R} \& \mathrm{C}) \\
\text { F2 } \\
\text { R1 }(\mathrm{R} \& \mathrm{C})\end{array}$ & $\begin{array}{l}\text { GTAAGTGATACAGTTGTAGAACC } \\
\text { CATTATTAGGAATCCACTCAAC } \\
\text { GTTGAGTGGATTCCTAATAATG } \\
\text { CCTTCACCAGTGTACCAGTG }\end{array}$ & 55 & 182 \\
\hline $\begin{array}{l}\text { Prolyl tRNA first } \\
\text { round }\end{array}$ & $\begin{array}{l}\mathrm{F} 1 \\
\mathrm{R} 1(\mathrm{R} \& \mathrm{C})\end{array}$ & $\begin{array}{l}\text { ATGAAGATTTATTAGCTGTGCC } \\
\text { GGAATACCTTTAAGTTCGCAG }\end{array}$ & 55 & 496 \\
\hline $\begin{array}{l}\text { Prolyl tRNA second } \\
\text { round }\end{array}$ & $\begin{array}{l}\text { F1 } \\
\text { R3 }(\mathrm{R} \& \mathrm{C}) \\
\text { F2 } \\
\text { R1 }(\mathrm{R} \& \mathrm{C})\end{array}$ & $\begin{array}{l}\text { ATGAAGATTTATTAGCTGTGCC } \\
\text { CTCAGAAGCTACGTCATCAC } \\
\text { GTGATGACGTAGCTTCTGAG } \\
\text { GGAATACCTTTAAGTTCGCAG }\end{array}$ & 55 & 316 \\
\hline $\begin{array}{l}\text { Arginyl tRNA first } \\
\text { round }\end{array}$ & $\begin{array}{l}\mathrm{F} 1 \\
\mathrm{R} 1(\mathrm{R} \& \mathrm{C})\end{array}$ & $\begin{array}{l}\text { ATGGAAGAAGGTATAAATGAGG } \\
\text { GGTCCCAGTGATTCACCTTT }\end{array}$ & 55 & 668 \\
\hline $\begin{array}{l}\text { Arginyl tRNA first \& } \\
\text { second round }\end{array}$ & $\begin{array}{l}\text { F2 } \\
\text { R1 }(\mathrm{R} \& \mathrm{C}) \\
\text { F1 } \\
\text { R2(R\&C) }\end{array}$ & $\begin{array}{l}\text { TTAGTTACAGGCATGTCAACC } \\
\text { GGTCCCAGTGATTCACCTTT } \\
\text { ATGGAAGAAGGTATAAATGAGG } \\
\text { GGTTGACATGCCTGTAACTAA }\end{array}$ & $\begin{array}{l}55 \\
55\end{array}$ & $\begin{array}{l}242 \\
447\end{array}$ \\
\hline HSP70 first round & $\begin{array}{l}\mathrm{F} 1 \\
\mathrm{R} 2(\mathrm{R} \& \mathrm{C})\end{array}$ & $\begin{array}{l}\text { AGAGACAAGCAACAAAAGATGC } \\
\text { CAGCTGATATTTTCAACTTATTCAA }\end{array}$ & 57 & 336 \\
\hline $\begin{array}{l}\text { HSP70 first \& } \\
\text { second round }\end{array}$ & $\begin{array}{l}\text { F1 } \\
\text { R1 }(\mathrm{R} \& \mathrm{C}) \\
\text { F2 } \\
\text { R2 }(\mathrm{R} \& \mathrm{C})\end{array}$ & $\begin{array}{l}\text { AGAGACAAGCAACAAAAGATGC } \\
\text { CACTATCAAAATCTTCTCCTCC } \\
\text { GGAGGAGAAGATTTTGATAGTG } \\
\text { CAGCTGATATTTTCAACTTATTCAA }\end{array}$ & $\begin{array}{l}57 \\
57\end{array}$ & 240 \\
\hline $\begin{array}{l}\text { RNA polymerase } \\
\text { first round }\end{array}$ & $\begin{array}{l}\mathrm{F} 1 \\
\mathrm{R} 1(\mathrm{R} \& \mathrm{C})\end{array}$ & $\begin{array}{l}\text { AGTGAGATTAGATCTGTACCTG } \\
\text { GGATGTATTTCACAATGTGTATAT }\end{array}$ & 57 & 1400 \\
\hline $\begin{array}{l}\text { RNA polymerase } \\
\text { first \& second round }\end{array}$ & $\begin{array}{l}\text { F1 } \\
\text { R2 }(\mathrm{R} \& \mathrm{C}) \\
\text { F2 } \\
\text { R1 }(\mathrm{R} \& \mathrm{C})\end{array}$ & $\begin{array}{l}\text { AGTGAGATTAGATCTGTACCTG } \\
\text { GGTGTATTTACACGTCTTAAATG } \\
\text { CATTTAAGACGTGTAAATACACC } \\
\text { GGATGTATTTCACAATGTGTATAT }\end{array}$ & 57 & $\begin{array}{l}779 \\
644\end{array}$ \\
\hline $\begin{array}{l}\text { Chitin synthase first } \\
\text { round }\end{array}$ & $\begin{array}{l}\text { F1 } \\
\text { R1 }(\mathrm{R} \& \mathrm{C})\end{array}$ & $\begin{array}{l}\text { TGACAGGATGAGTGATGTGG } \\
\text { GACTAATATAATACTCAAACACTT }\end{array}$ & 55 & 254 \\
\hline
\end{tabular}

Terminator $\mathrm{v} 3 \cdot 1$ cycle sequencing kit (Thermo Fisher Scientific, UK) with relevant primers (Tables 2 and 3) and the following PCR thermal cycling program: $94^{\circ} \mathrm{C} \times 30 \mathrm{~s}$ followed by 30 cycles of $96{ }^{\circ} \mathrm{C} \times 10 \mathrm{~s}, 50{ }^{\circ} \mathrm{C} \times 10 \mathrm{~s}$ and $60{ }^{\circ} \mathrm{C} \times 4 \mathrm{~min}$ and held at $4{ }^{\circ} \mathrm{C}$. Analyses of the sequenced PCR product were done using the Sequencher software (Gene codes corporation).

\section{Construction of a six-gene phylogenetic tree}

Maximum likelihood (ML) analyses. The orthologues for each gene set were individually aligned with the command line MUSCLE program (v3·8.31) (Edgar, 2004) using the default settings, and then subsequently masked with the automatic command line tool TrimAl (Capella-Gutierrez et al. 2009). Saccharomyces cerevisiae was used as an out-group in each of the microsporidian datasets.

A GTR substitution model with a gamma model of rate heterogeneity was used to create ML trees for the individual gene sets with the RaxML program (Stamatakis, 2014). These were pilot trees to check for unusually long-branch lengths indicative of unlikely orthologues. The masked genes from each microsporidian species were subsequently manually concatenated using SeaView (v4) (Gouy et al. 2010). For the final construction of the ML concatenated gene tree, a partition file that contained the positions of the individual genes within the alignment was manually created and passed to the RaxML program using the ' $-\mathrm{q}$ ' option (Stamatakis, 2014). This was to enable the program to treat each gene set in the concatenated alignment separately and allow it to estimate individual nucleotide substitution rates. These estimations were also performed with the GTR + GAMMA nucleotide substitution model.

Bayesian inference analysis on six-gene concatenated alignment. To check for reliability of the phylogenetic relationships estimated by ML analyses, a Bayesian inference method was also used to reconstruct the six-gene concatenated phylogenetic tree using MrBayes program (v3·2) (Ronquist et al. 2012). A partition file containing positions of the individual genes in the alignment was created according to the program manual. The program was run 
Table 3. rDNA primers used in this study

\begin{tabular}{|c|c|c|c|c|c|}
\hline Gene & Primer name & Sequence & $\begin{array}{l}\text { Annealing } \\
\text { temp }\left({ }^{\circ} \mathrm{C}\right)\end{array}$ & $\begin{array}{l}\text { Size of product } \\
\text { approx. bp }\end{array}$ & Reference \\
\hline \multirow[t]{2}{*}{ SSU } & $530 \mathrm{~F}$ & GTGCCATCCAGCCGCGG & \multirow[t]{2}{*}{55} & \multirow[t]{2}{*}{$1350-1550$} & \multirow{2}{*}{$\begin{array}{l}\text { Docker et al. } \\
\text { (1997) }\end{array}$} \\
\hline & $580 \mathrm{R}$ & GGTCCGTGTTTCAAGACGG & & & \\
\hline SSU & $\begin{array}{l}\text { MF1 } \\
\text { MR1 }\end{array}$ & $\begin{array}{l}\text { CCGGAGAGGGAGCCTGAGA } \\
\text { GACGGGCGGTGTGTACAAA }\end{array}$ & 55 & 848 & $\begin{array}{l}\text { Tourtip et al. } \\
(2009)\end{array}$ \\
\hline SSU & $\begin{array}{l}\text { Medlin B (used } \\
\text { with MF1) }\end{array}$ & GATCCTTCTGCAGGTTCACCT & 55 & 1500 & $\begin{array}{l}\text { Medlin et al. } \\
\text { (1988) }\end{array}$ \\
\hline
\end{tabular}

using a GTR + GAMMA model and probability distributions were generated using the Markov Chain Monte Carlo Methods. A total of 1020000 generations were run, the first $25 \%$ of sampled trees were discarded as 'burn-in' and a consensus tree was constructed.

\section{RESULTS}

\section{Pathology, ultrastructure and SSU-based phylogeny}

Infected hepatopancreatic tubules from all three crab hosts displayed varying proportions of infected epithelial cells consistent with previous descriptions of Hepatospora-associated pathology (Stentiford et al. 2011). Infection was confined to the epithelial cells of the hepatopancreas, with no other organ seemingly infected. However, in some severe cases where hepatopancreatic tubules were disrupted, liberated parasite spores could be observed within the lumen of affected tubules and, in the haemolymph. Histologically, the disease caused by this microsporidian was indistinguishable between Chinese mitten crab (where the parasite has been confirmed as H. eriocheir), edible crab and pea crab (Fig. 1).

Ultrastructural analysis revealed multiple stages of a microsporidian parasite within the cytoplasm of hepatopancreatic epithelial cells of each host crab species. The earliest stage observed was the meront (Fig 2A, $\mathrm{C}$ and E). Hepatospora eriocheir (infecting Chinese mitten crab) possessed uni-nucleate meronts, whereas the parasite infecting pea crab and edible crab possessed bi-nucleate meronts. A similar observation was made in the spore stages with spores (Fig 2B, D and F) from the parasite infecting edible crab and pea crab appearing bi-nucleate, while spores from the Chinese mitten crab were of uni-nucleate karyotype. Mature spores in all cases possessed a trilaminar wall consisting of a plasma membrane, an electron lucent endospore and an electron-dense exospore. Spores measured 1.8-1.9 $\times 0.9 \mu \mathrm{m}$ but contained varying turns of an isofilar polar filament. Spores from the parasite-infecting Chinese mitten crabs and edible crabs possessed seven to eight turns of the polar filament while those from the parasiteinfecting pea crabs possessed five to six turns of the polar filament. A summary of these shared and distinctive features is given in Table 1 .
Partial sequencing of the SSU rDNA gene obtained from the parasites infecting the three host crab species revealed an apparent synonymy $(\approx 99 \%$ similarity over $890 \mathrm{bp}$ ), at least based upon this portion of the SSU, between the three parasites. Despite some ultrastructural and karytopic distinctions between the three isolates (Table 1), SSUbased phylogeny did not support erection of distinctive taxa for the parasites infecting edible crab and pea crab. Based upon SSU phylogeny, these parasites would therefore be classified as $H$. eriocheir, with edible crab and pea crab representing an extended host range for this parasite.

\section{Phylogeny of Hepatospora isolates based upon six concatenated genes}

Taking in to account the potential weakness of SSUbased phylogenies for discriminating closely related microsporidian (and other) taxa, phylogenies based upon alternative (coding) regions of the Hepatospora genome were constructed to investigate their potential as taxonomic discriminators (GenBank accession nos. of Hepatospora genes used: KU695715, KU695716, KU695717, KU695718, KU695719, KU695720, KU695721, KU695722, KU695723, KU695724, KU695725, KU695726, KU695727, KU695728, KU695729, KU695730, KU695731, KU695732). The resulting alignment of the six masked concatenated genes consisted of 18232 sites. Phylogenetic trees based on ML and BI methods displayed identical topologies and strongly supported the grouping of the Chinese mitten crab parasite $H$. eriocheir, the edible crab and pea crab parasites, and the placement of E. cuniculi strains and Nematocida spp. as distinct clades with high confidence values (Fig. 4). The clade consisting of $H$. eriocheir, the edible crab parasite and the pea crab parasites branched as a sister group to Enterocytozoon bieneusi as consistent with previously phylogenies based upon SSU gene sequences (Stentiford et al. 2011). Our tree is also consistent with a previous multi-protein microsporidian phylogeny showing the Enterocytozoonidae forming a clade with Vittaforma corneae and with the Nosema/Encephalitozoon clade as a sister group to these (Nakjang et al. 2013). Within our tree, all resequenced strains are retrieved as clades with few 

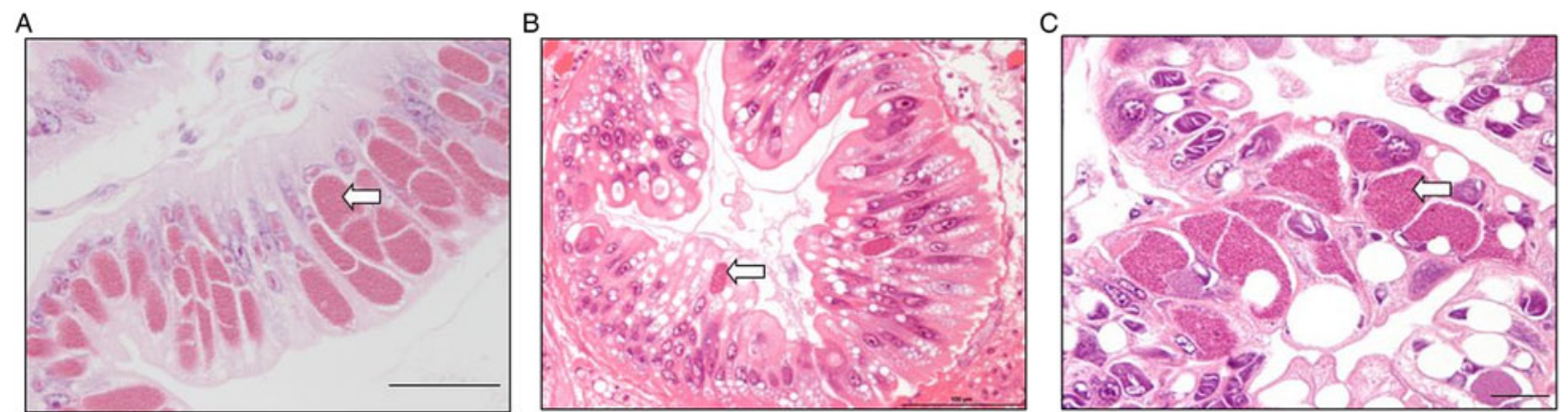

Fig. 1. (A) Histopathology of Hepatospora sp. in the hepatopancreas of E. sinensis. Scale $=50 \mu \mathrm{m}$. (B) Histopathology of H. eriocheir in the hepatopancreas of Cancer pagurus. Scale $=100 \mu \mathrm{m}$. (C) Histopathology of Hepatospora sp. in the hepatopancreas of $P$. pisum. Scale $=25 \mu \mathrm{m}$. Tubule epithelial cells contained multiple granular inclusions (arrows) All images H\&E histology.

nucleotide differences separating them. As observed for our crab pathogens, no nucleotide differences separated strains of Nematocida sp. or Nematocida parisii, in our analysis. Nucleotide differences do however separate $E$. cuniculi EC1-3 strains from $E$. cuniculi $\mathrm{GB}$ and $E$. hellem swiss from $E$. hellem ATCC. The six gene concatenated phylogeny supports the proposition from our SSU-based phylogeny that the parasites infecting Chinese mitten crabs, European edible crabs and, pea crabs can all be classified as $H$. eriocheir. Further, it provides firm evidence that $H$. eriocheir (or very closely related microvariants thereof) can infect a wide variety of decapods crustaceans from different aquatic habitats.

\section{DISCUSSION}

Phylogenetic analyses performed with rDNA have been pivotal in erecting new taxa and in the discovery of morphological plasticity within the microsporidian phylum but have however been unsuccessful in resolving the branching relationships between closely related species. The Hepatospora genus is a recent taxa erected as a result of modern phylogenetic techniques (Stentiford et al. 2011). It has been defined as a genus that encompasses microsporidia with infective life stages that develop within the hepatopancreas of marine and brackish water hosts. With the use of rDNA-based phylogenetic analyses, Stentiford et al. (2011) renamed and updated the description of Endoreticulatus eriocheir (Wang and Chen, 2007) to form the type species $H$. eriocheir. Unlike Wang and Chen who isolated their spores from native Chinese mitten crabs, the spores in the Stentiford et al. (2011) study were isolated from invasive Chinese mitten crabs (E. sinensis) which had been caught in the Thames estuary, UK. In both studies, the spores were described as ellipsoid, measuring $\sim 1.8 \times 0.9 \mu \mathrm{m}$ and containing seven to eight polar filaments. Recently, Ding et al. (2016) have shown that not only is the pathogen infecting the
Asian population of Chinese mitten crabs H. eriocheir, but also the infection is associated with an emerging disease condition causing significant proportions in aquaculture production of this species in China. In their original taxonomic paper, Stentiford et al. (2011) also highlighted an unassigned microsporidian infecting the hepatopancreas of edible crabs, C. pagurus, and suggested at the time that this was also likely a member of the genus Hepatospora based upon high similarity with the partial SSU gene sequence from $H$. eriocheir.

In 2012, Longshaw et al. produced a disease profile of the pea crab ( $P$. pisum) revealing the presence of two uncategorized microsporidian parasites. One of these appeared to be cytoplasmic, residing in hepatopancreatocytes and inducing a necrotizing effect that resulted in the degeneration of hepatopancreatic tubules. However, in this study, the microsporidian was not assigned a taxon and no further data was presented in order to aid its molecular or morphological characterization.

In the present study, we have shown that infection with the parasite of the hepatopancreas of edible crabs displays a similar pathology to that caused by infection with $H$. eriocheir in Chinese mitten crabs from London (Stentiford et al. 2011) and from China (Wang and Chen, 2007; Ding et al. 2016), and to the infection described in pea crabs by Longshaw et al. (2012). These parasites also appear to share a broadly similar morphological development within host gut epithelial cells albeit with some distinctive differences in karyo-status (H. eriocheir is unikaryotic whereas the pea crab and edible crab parasites are dikaryotic) and some minor differences in polar tube-coiling patterns (summarized in Table 1). Based upon our analysis of rDNA gene sequencebased phylogenetic relationship between $H$. eriocheir and the two novel parasites, all three are virtually indistinguishable, forming a monophyletic group immediately adjacent to the Enterocytozoonidae clade (Stentiford et al. 2013) (see Fig. 3).

Based upon the somewhat surprising finding that the same parasite taxon appeared to infect not only 

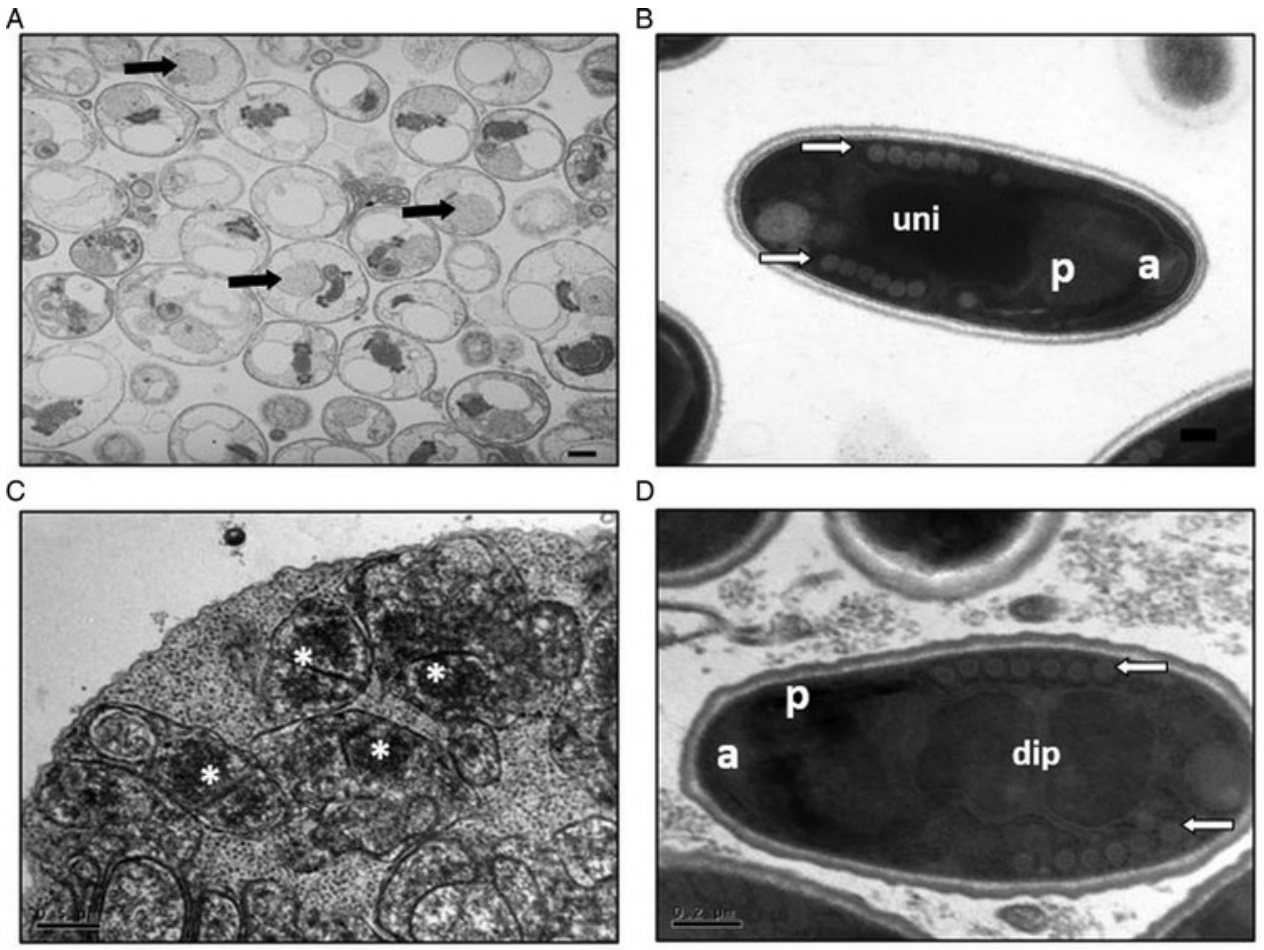

$\mathrm{F}$
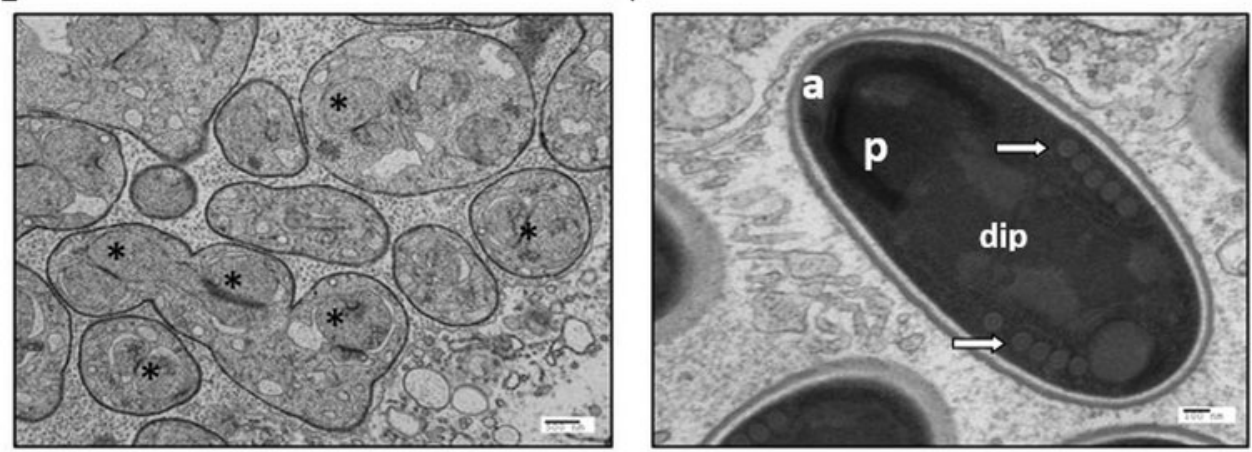

Fig. 2. Electron micrographs of H. eriocheir from E. sinensis (A and B) and Hepatospora sp. from Cancer pagurus (C and D) and $P$.pisum (E and F). (A) Developing sporonts within a parasitophorous vesicle. Sporonts contain multiple unikaryotic nuclei (arrows) which then divide and mature to form spores. Scale bar $=500 \mathrm{~nm}$. (B) Mature spore containing seven to eight turns of the polar filament (arrow) in single file, unikaryotic nucleus (uni), anchoring disc (a) and polaroplast (p). Scale bar $=100 \mathrm{~nm}$. (C) Developing sporonts within a parasitophorous vesicle. Sporonts contain multiple diplokaryotic nuclei (*) which then divide and mature to form spores. Scale bar $=0 \cdot 5 \mu \mathrm{m}$. (D) Mature spore containing five to six turns of the polar filament (arrow) in single file, diplokaryotic nucleus (dip), anchoring disc (a) and polaroplast (p). Scale bar $=0 \cdot 2$ $\mu \mathrm{m}$. (E) Developing sporonts within a parasitophorous vesicle. Sporonts contain multiple diplokaryotic nuclei (*) which then divide and mature to form spores. Scale bar $=500 \mathrm{~nm}$. (F) Mature spore containing five to six turns of the polar filament (arrow) in single file, diplokaryotic nucleus (dip), anchoring disc (a) and polaroplast (p). Scale bar $=100 \mathrm{~nm}$.

Chinese mitten crabs from different parts of their invasive/native range, but also occurred in nicheseparated crab hosts from the European marine environment we used these three microsporidians as a model system to assess how a concatenated multi-gene phylogenetic approach could be applied as refined tool for discriminating taxa which cannot be separated by rDNA-based phylogenetic approaches. As outlined in our recent Opinion piece, appropriate application of such techniques may be suitable where significant biological reasoning exists for potential separation of taxa (e.g. one causing disease and another not) and, may be particularly important where pathogens are to be listed to prevent their international trade in animals and their products (Stentiford et al. 2014). The model system presented by Hepatospora was appropriate given the potential for geographical, host and habitat distinction between known isolates, some reasonably significant differences in morphology (i.e. karyotstatus) and, the availability of draft genome data for the best studied of these, H. eriocheir. The rationale behind this concatenated phylogeny approach was to look for alternatives or additional data with which to resolve the branching relationship between very closely related 


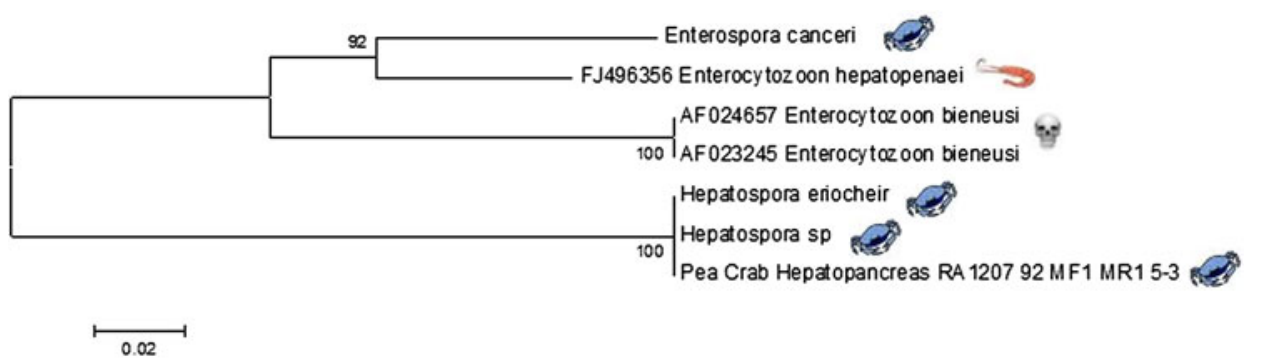

Fig. 3. Neighbour - joining tree based on a 511 bp nucleotide partial SSU 18 s sequence from parasites isolated from hepatopancreas of E. sinensis (H. eriocheir), Cancer pagurus (Hepatospora sp.) and P. pisum. The phylogenetic analysis was performed using Mega version 5·05. Analysis was done using 1000 bootstrapped datasets and values $>70 \%$ are shown on the tree. The scale bar represents substitutions per nucleotide site.

microsporidia. Despite this reasoning, our concatenated phylogenies resulted in almost identical tree topologies in both the ML and BI probabilistic approaches used with nodes supported by high bootstrap and posterior probability values, respectively. This, in addition to the retrieval of well-known relationships like the grouping of Encephalitozoon and Nematocida strains (in Fig. 4) and overall tree topology similar to previously published work based on rDNA genes (Troemel et al. 2008; Stentiford et al. 2011; Cuomo et al. 2012) increases our confidence in the phylogenetic relationships inferred by our study.

Whilst our multi-gene phylogeny confirms the close relationship of the three isolates, it does not discriminate well between them. This is in part due to the use of highly conserved genes for our concatenated tree phylogenetic analyses. Even though protein-coding genes have been successfully used in previous studies to infer deep phylogenetic relationships within the microsporidian phylum and placing microsporidians within the tree of life (Fast et al. 1999; Hirt et al. 1999; Keeling, 2003; Nakjang et al. 2013), the selected genes were unable to properly resolve branching relationships in our analyses due to the high level of nucleotide sequence similarity between the three Hepatospora strains (Table 1 and Fig. 3). Due to the small size of the pea crab hepatopancreas and very low infection levels in this host, we were unable to extract a large quantity of parasite genomic DNA. This in turn limited the number of marker genes we could amplify from the pea crab parasite for this study. Given more material we would have amplified further genes, for example polar tube and spore wall protein-coding genes. These have been used in previous studies to distinguish between Encephalitozoon and Nosema strains (Peuvel et al. 2000; Polonais et al. 2010; Chaimanee et al. 2011), and could have been added in our analyses to improve the resolution of branching relationships between the Hepatospora strains. It must however be noted that even though Polonais et al. (2010) were successful in differentiating between Encephalitozoon hellem strains by looking at nucleotide polymorphisms at the spore wall protein gene, this gene was unsuccessful in differentiating between Nosema ceranae geographical isolates in similar recent studies (Roudel et al. 2013; Van der Zee et al. 2014). This highlights the different evolutionary pressures acting on the genes and possibly genomes of different microsporidians and that a gene successfully used to differentiate between strains in one microsporidian species may not be ideal for other species.

Future studies of this kind should probably focus on divergent single copy orthologues between strains of interest. Primer design for more variable genes is more challenging, but the advent of single-cell sequencing will remove this issue completely. As microsporidian genomes become increasingly available, we envisage a switch from phylogenetics to phylogenomics as the latter presents a more holistic approach to understanding close phylogenetic relationships and providing information for more robust taxonomic assignments.

\section{Taxonomy of Hepatospora}

Despite the caveats exposed in the preceding section, it is useful to consider the taxonomic placement of the parasites infecting the three host crabs. Here, it is useful to look to other genera within the phylum. Since already established subspecies of E. cuniculi, E. hellem and Nematocida (also included within our analysis) have nucleotide similarity for the same genes used in this study ranging between $92 \cdot 13$ and $99 \cdot 95 \%$, assigning different species names to the host-specific isolates of Hepatospora (98.53-98.88\% nucleotide similarity) is not supported (see highlighted boxes in Table 4). On the bases of their high nucleotide similarity and their consequent grouping with minimal branching distances on our multi-gene phylogenetic tree (shown in bold in Fig. 4), we propose that Hepatospora parasites investigated in the current study should therefore be regarded as the same species, $H$. eriocheir, or potentially very closely related microvariants thereof. However, in consideration of the differences in morphological features that would have placed these microsporidians in completely different 
A

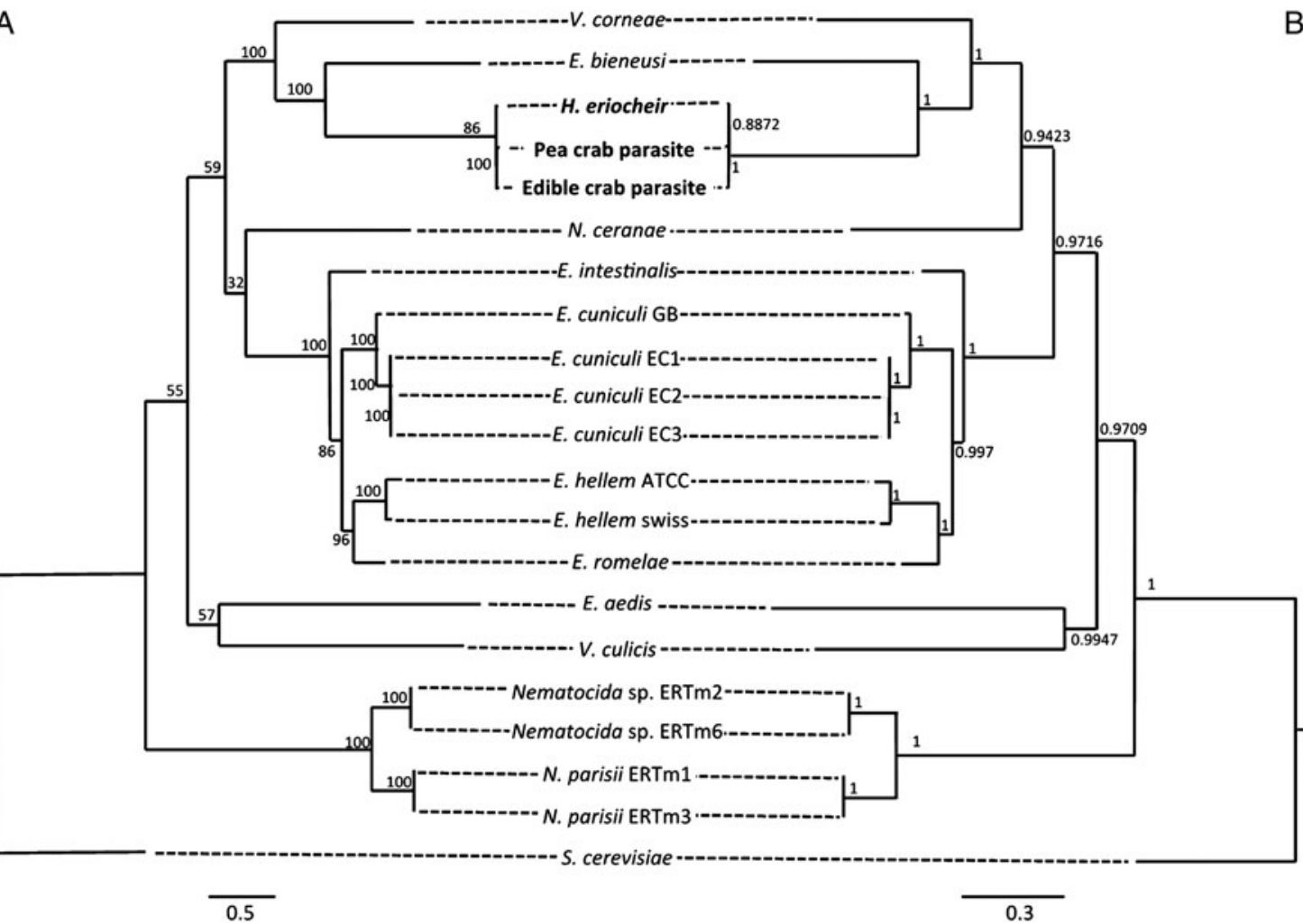

Fig. 4. Grouping of three Hepatospora/Hepatospora-like species suggests they are closely related. Phylogenetic trees based on (A.) maximum likelihood, (B.) Bayesian inference of 20 microsporidians for six concatenated genes rooted with $S$. cerevisiae. Numbers on nodes are (A.) Bootstrap confidence levels from 100 replicates, (B.) Bayesian posterior probability values. Both trees displaying identical topologies and grouping of Hepatospora/Hepatospora-like clade are shown in bold. The scale bars represent nucleotide substitutions per site.

Table 4. High nucleotide sequence similarity of the six marker genes used in this study between the parasites isolated from three different crab hosts

\begin{tabular}{lllllll}
\hline \hline & $\begin{array}{l}\text { arginyl tRNA } \\
\text { synthetase }\end{array}$ & $\begin{array}{l}\text { prolyl tRNA } \\
\text { synthetase }\end{array}$ & $\begin{array}{l}\text { beta- } \\
\text { tubulin }\end{array}$ & $\begin{array}{l}\text { chitin } \\
\text { synthase }\end{array}$ & HSP70 & $\begin{array}{l}\text { RNA } \\
\text { polymerase II }\end{array}$ \\
\hline $\begin{array}{l}\text { H. eriocheir vs Pea crab } \\
\text { parasite }\end{array}$ & $\mathbf{9 9} 21 / 669$ & $\mathbf{9 8} 8 / 482$ & $\mathbf{9 9} 1 / 643$ & $\mathbf{1 0 0} 0 / 228$ & $\mathbf{1 0 0} 0 / 305$ & $\mathbf{9 9} 14 / 1341$ \\
$\begin{array}{l}\text { H. eriocheir vs Edible } \\
\text { crab parasite }\end{array}$ & $\mathbf{9 9} 23 / 1064$ & $\mathbf{9 9} 29 / 1401$ & $\mathbf{9 9} 6 / 1200$ & $\mathbf{9 9} 15 / 2211$ & $\mathbf{9 9} 6 / 744$ & $\mathbf{9 9} 22 / 3303$ \\
$\begin{array}{l}\text { Edible crab parasite vs } \\
\text { Pea crab parasite }\end{array}$ & $\mathbf{9 9} 20 / 669$ & $\mathbf{9 9} 1 / 482$ & $\mathbf{9 9} 1 / 643$ & $\mathbf{1 0 0} 0 / 228$ & $\mathbf{9 9} 4 / 305$ & $\mathbf{9 9} 15 / 1341$ \\
\hline \hline
\end{tabular}

Numbers in bold are percentage identity comparison of sites (i.e. nucleotides + gaps) resulting from the alignment of each of the six marker genes of three Hepatospora/Hepatospora-like microsporidian species. Italicized numbers represent number of variable nucleotides in the pairwise alignment of two species without taking gaps into account (number given of variable nucleotides/total number of aligned nucleotides).

taxonomic ranks using traditional approaches (and considering that taxonomy of the phylum abides by rules laid down by the $I C Z N$ ), it is perhaps appropriate to consider these microvariants as subspecies. We therefore propose the assignment of $H$. eriocheir pinnotheres and H. eriocheir canceri as subspecies of $H$. eriocheir infecting the pea crab and edible crab, respectively. Regardless of use of particular nomenclature, it is noteworthy that the genus Hepatospora (and perhaps specifically its type taxon $H$. eriocheir) may represent an example of a parasite cline, infecting the guts of one of the most abundant host groups in our oceans, the crustaceans. The minor differences in rDNA-based and even concatenated phylogenies for Hepatospora may underlie a subtly shifting genome required for survival in hosts from different habitats. As more subspecies are discovered from variant hosts in different habitats, the concept of the parasite cline can be better studied.

An alternative hypothesis would reflect the potential that a previously host-specific parasite, $H$. eriocheir has been inadvertently introduced to European waters by its invasive host, the Chinese mitten crab; following 
which it has subsequently switched to hosts which at least have niche overlap at some point in their life cycle (Ingle, 1980; Lawton, 1989; Clark et al. 1998; Becker and Türkay, 2010). The description of gut infecting microsporidian taxa from locations where such niche overlap are absent will address this key question.

\section{ACKNOWLEDGEMENTS}

The authors would like to thank Dr Matt Longshaw and Mr Jamie Bojko for their assistance in obtaining samples of pea crabs.

\section{FINANCIAL SUPPORT}

This work was supported by the Department of Environment, Food and Rural Affairs (DEFRA) under Contract Number FB002 (to Dr Stephen Feist, Project Manager and liaison between Cefas and Defra).

\section{REFERENCES}

Aurrecoechea, C., Barreto, A., Brestelli, J., Brunk, B. P., Caler, E. V., Fischer, S., Gajria, B., Gao, X., Gingle, A., Grant, G., Harb, O. S., Heiges, M., Iodice, J., Kissinger, J. C., Kraemer, E. T., Li, W., Nayak, V., Pennington, C., Pinney, D. F., Pitts, B., Roos, D.S., Srinivasamoorthy, G., Stoeckert, C. J., Jr., Treatman, C. and Wang, H. (2011). AmoebaDB and MicrosporidiaDB: functional genomic resources for Amoebozoa and Microsporidia species. Nucleic Acids Research 39, D612- D619.

Ausubel, F. M., Brent, R., Kingston, R. B., Moore, D. D., Seidman, J. G., Smith, J. A. and Struhl, K. (2002). Current Protocols in Molecular Biology. John Wiley \& Sons Inc.

Bateman, K. S., Hicks, R. J. and Stentiford, G. D. (2011). Disease profiles differ between non-fished and fished populations of edible crab (Cancer pagurus) from a major commercial fishery. ICES fournal of Marine Science 68, 2044-2052.

Becker, C. and Türkay, M. (2010). Taxonomy and morphology of European pea crabs (Crustacea: Brachyura: Pinnotheridae). Fournal of Natural History 44, 1555-1575.

Brown, J. R. and Doolittle, W. F. (1999). Gene descent, duplication, and horizontal transfer in the evolution of glutamyl- and glutaminyl-tRNA synthetases. Fournal of Molecular Evolution 49, 485-495.

Cali, A., Kotler, D. P. and Orenstein, J. M. (1993). Septata intestinalis N. G., N. Sp., an intestinal microsporidian associated with chronic diarrhea and dissemination in AIDS patients. Fournal of Eukaryotic Microbiology 40, 101-112.

Canning, E. U. (1953). A new microsporidian, Nosema locustae n.sp., from the fat body of the African migratory locust, Locusta migratoria migratoria ides R. \& F. Parasitology 43, 287-290.

Capella-Gutierrez, S., Silla-Martinez, J. M. and Gabaldon, T. (2009). trimAl: a tool for automated alignment trimming in large-scale phylogenetic analyses. Bioinformatics 25, 1972-1973.

Capella-gutiérrez, S., Marcet-houben, M. and Gabaldón, T. (2012). Phylogenomics supports microsporidia as the earliest diverging clade of sequenced fungi. BMC Biology 10, 47

Chaimanee, V., Chen, Y., Pettis, J.S., Scott Cornman, R.and Chantawannakul, P. (2011). Phylogenetic analysis of Nosema ceranae isolated from European and Asian honeybees in Northern Thailand. Fournal of Invertebrate Pathology 107, 229-233.

Clark, P. F., Rainbow, P. S., Robbins, R. S., Smith, B., Yeomans, W. E., Thomas, M. and Dobson, G. (1998). The alien Chinese mitten crab, Eriocheir sinensis (Crustacea : Decapoda : Brachyura), in the Thames catchment. Fournal of the Marine Biological Association 78, 1215-1221.

Corradi, N. and Keeling, P. J. (2009). Microsporidia: a journey through radical taxonomical revisions. Fungal Biology Reviews 23, 1-8.

Cuomo, C. A., Desjardins, C. A., Bakowski, M. A., Goldberg, J., Ma, A. T., Becnel, J. J., Didier, E.S., Fan, L., Heiman, D. I., Levin, J.Z., Young, S., Zeng, Q. and Troemel, E. R. (2012). Microsporidian genome analysis reveals evolutionary strategies for obligate intracellular growth. Genome Research 22, 2478-2488.
Darken, M. A. (1962). Absorption and transport of fluorescent brighteners by microorganisms. Applied Microbiology 10, 387.

Ding, Z.-F., Meng, Q.-G., Liu, H.-Y., Yuan, S., Zhang, F.-X., Sun, M.L., Zhao, Y.-H., Shen, M.-F., Zhou, G., Pan, J.-L., Wang, W. and Xia, A.-J. (2016). First case of hepatopancreatic necrosis disease (HPND) in pond-reared Chinese mitten crab, Eriocheir sinensis associated with microsporidian. Fournal of Fish Diseases doi: 10.1111/jfd.12437.

Docker, M. F., Kent, M. L., Hervio, D. M. L., Khattra, J. S., Weiss, L. M., Cali, A. and Devlin, R. H. (1997). Ribosomal DNA sequence of Nucleospora salmonis Hedrick, Groff and Baxa, 1991 (Microsporea: Enterocytozooidae): Implications for phylogeny and nomenclature. Fournal of Eukaryotic Microbiology 44, 55-60.

Edgar, R. C. (2004). MUSCLE: multiple sequence alignment with high accuracy and high throughput. Nucleic Acids Research 32, 1792-1797.

Edlind, T., Visvesvara, G., Li, J. and Katiyar, S. (1994). Cryptosporidium and microsporidial beta-tubulin sequences: predictions of benzimidazole sensitivity and phylogeny. Fournal of Eukaryotic Microbiology 41, 38S.

Fast, N. M., Logsdon, J. M. and Doolittle, W. F. (1999). Phylogenetic analysis of the TATA box binding protein (TBP) gene from Nosema locustae: evidence for a microsporidia-fungi relationship and spliceosomal intron loss. Molecular Biological Evolution 16, 1415-1419.

Gouy, M., Guindon, S. and Gascuel, O. (2010). SeaView version 4: a multiplatform graphical user interface for sequence alignment and phylogenetic tree building. Molecular Biological Evolution 27, 221-224.

Gresoviac, S. J., Khattra, J. S., Nadler, S. A., Kent, M. L., Devlin, R. H., Vivares, C. P., Fuente, E. and Hedrick, R. P. (2000). Comparison of small subunit Ribosomal RNA gene and internal transcribed spacer sequences among isolates of the intranuclear microsporidian Nucleospora salmonis. Fournal of Eukaryotic Microbiology 47, 379-387.

Hinkle, G., Morrison, H. G. and Sogin, M. L. (1997). Genes coding for reverse transcriptase, DNA-directed RNA polymerase, and chitin synthase from the microsporidian Spraguea lophii. Biological Bulletin 193, 250-251. Hirt, R.P., Healy, B., Vossbrinck, C. R., Canning, E. U. and Embley, T. M. (1997). A mitochondrial Hsp70 orthologue in Vairimorpha necatrix: molecular evidence that microsporidia once contained mitochondria. Current Biology 7, 995-998.

Hirt, R. P., Logsdon, J. M., Healy, B., Dorey, M. W., Doolittle, W. F. and Embley, T. M. (1999). Microsporidia are related to Fungi: evidence from the largest subunit of RNA polymerase II and other proteins. Proceedings of the National Academy of Sciences of the United States of America 96, 580-585

Ingle, R. W. (1980). British Crabs. Oxford University Press and British Natural History Museum, London.

Ironside, J. E. (2013). Diversity and recombination of dispersed ribosomal DNA and protein coding genes in microsporidia. PLoS ONE 8, e55878. James, T. Y., Pelin, A., Bonen, L., Ahrendt, S., Sain, D., Corradi, N. and Stajich, J.E. (2013). Shared signatures of parasitism and phylogenomics unite Cryptomycota and Microsporidia. Current Biology 23 1548-1553.

Keeling, P. J. (2003). Congruent evidence from $\alpha$-tubulin and $\beta$-tubulin gene phylogenies for a zygomycete origin of microsporidia. Fungal Genetics and Biology 38, 298-309.

Kent, M. L., Hervio, D. M. L., Docker, M. F. and Devlin, R. H. (1996) Taxonomy studies and diagnostic tests for Myxosporean and Microsporidian pathogens of Salmonid fishes utilising Ribosomal DNA sequence. Fournal of Eukaryotic Microbiology 43, 98S-99S.

Lawton, P. (1989). Predatory interaction between the brachyuran crab Cancer pagurus and decapod crustacean prey. Marine Ecology Progress Series 52, 169-179.

Longshaw, M., Feist, S. W. and Bateman, K. S. (2012). Parasites and pathogens of the endosymbiotic pea crab (Pinnotheres pisum) from blue mussels (Mytilus edulis) in England. Fournal of Invertebrate Pathology 109, 235-242.

Mathis, A., Weber, R. and Deplazes, P. (2005). Zoonotic potential of the microsporidia. Clinical Microbiology Reviews 18, 423-445.

Medlin, L., Elwood, H. J., Stickel, S. and Sogin, M. L. (1998). The characterization of enzymatically amplified eukaryotic 16S-like rRNAcoding regions. Gene 71, 91-499.

Mount, D.W. (2007) Using the basic local alignment search tool (BLAST). 22 Cold Spring Harbour Protocols. Adapted from "Sequence Database Searching for Similar Sequences," Chapter 6, in 2nd (eds David W. Mount), Cold Spring Harbor Laboratory Press, Cold Spring Harbor, NY, USA, 2004, doi: 10.1101/pdb.top17.

Nakjang, S., Williams, T. A., Heinz, E., Watson, A. K., Foster, P. G., Sendra, K. M., Heaps, S. E., Hirt, R. P. and Martin Embley, T. (2013). Reduction and expansion in microsporidian genome evolution: new insights from comparative genomics. Genome Biology Evolution 5, 2285-2303. 
O'Mahony, E. M., Tay, W. T. and Paxton, R. J. (2007). Multiple rRNA variants in a single spore of the microsporidian Nosema bombi. Fournal of Eukaryotic Microbiology 54, 103-109.

Peuvel, I., Delbac, F., Metenier, G., Peyret, P. and Vivares, C.P. (2000). Polymorphism of the gene encoding a major polar tube protein PTP1 in two microsporidia of the genus Encephalitozoon. Parasitology 121(Pt 6), 581-587.

Polonais, V., Mazet, M., Wawrzyniak, I., Texier, C., Blot, N., El Alaoui, H. and Delbac, F. (2010). The human microsporidian Encephalitozoon hellem synthesizes two spore wall polymorphic proteins useful for epidemiological studies. Infection and Immunity 78, 2221-2230. Reynolds, E. S. (1963). The use of lead citrate at high $\mathrm{pH}$ as an electronopaque stain in electron microscopy. Fournal of Cell Biology 17, 208-212. Ronquist, F., Teslenko, M., van der Mark, P., Ayres, D. L., Darling, A., Höhna, S., Larget, B., Liu, L., Suchard, M. A. and Huelsenbeck, J. P. (2012). MrBayes 3·2: efficient bayesian phylogenetic inference and model choice across a large model space. Systematic Biology 3, 539-542.

Roudel, M., Aufauvre, J., Corbara, B., Delbac, F. and Blot, N. (2013) New insights on the genetic diversity of the honeybee parasite Nosema ceranae based on multilocus sequence analysis. Parasitology 140, 1346-1356.

Sak, B., Kvác, M., Petrzelková, K., Kvetonová, D., Pomajbíková, K., Mulama, M., Kiyang, J. and Modrý, D. (2011). Diversity of microsporidia (Fungi: Microsporidia) among captive great apes in European zoos and African sanctuaries: evidence for zoonotic transmission? Folia Parasitologica 58, 81-86.

Shadduck, J. A., Meccoli, R. A., Davis, R. and Font, R. L. (1990) Isolation of a microsporidian from a human patient. Fournal of Infectious Diseases 162, 773-776.

Stamatakis, A. (2014). RAxML version 8: a tool for phylogenetic analysis and post-analysis of large phylogenies. Bioinformatics 30, 1312-1313.

Stentiford, G. D., Bateman, K. S., Dubuffet, A., Chambers, E. and Stone, D. M. (2011). Hepatospora eriocheir (Wang and Chen, 2007) gen et comb. nov. infecting invasive Chinese mitten crabs (Eriocheir sinensis) in Europe. Fournal of Invertebrate Pathology 108, 156-166.

Stentiford, G. D., Bateman, K. S., Feist, S. W., Chambers, E. and Stone, D. M. (2013). Plastic parasites: extreme dimorphism creates a taxonomic conundrum in the phylum Microsporidia. International Fournal of Parasitology 43, 339-352.

Stentiford, G. D., Feist, S. W., Stone, D. M., Peeler, E. J. and Bass, D. (2014). Policy, phylogeny, and the parasite. Trends in Parasitology 30, 274-281. Tamura, K., Peterson, D., Peterson, N., Stecher, G., Nei, M. and Kumar, S. (2011). MEGA5: molecular evolutionary genetics analysis using maximum likelihood, evolutionary distance, and maximum parsimony methods. Molecular Biology and Evolution 28, 2731-2739.

Tay, W. T., O'Mahony, E. M. and Paxton, R. J. (2005). Complete rRNA gene sequences reveal that the microsporidium Nosema bombi infects diverse bumblebee (Bombus spp.) hosts and contains multiple polymorphic sites. Fournal of Eukaryotic Microbiology 52, 505-513.

Tourtip, S., Wongtripop, S., Sritunyalucksana, K. S., Stentiford, G. D. Bateman, K. S., Sriurairatana, S., Chayaburakul, K., Chavadej, K. and Withyachumnarnkul, B. (2009). Enterocytozoon hepatopenaei sp. nov. (Microspora: Enterocytozoonidae), a parasite of the black tiger shrimp Penaeus monodon (Decapoda: Penaeidae): fine structure and phylogenetic relationships. Fournal of Invertebrate Pathology 102, 21-29.

Troemel, E. R., Félix, M.-A., Whiteman, N. K., Barrière, A. and Ausubel, F. M. (2008). Microsporidia are natural intracellular parasites of the nematode Caenorhabditis elegans. PLoS Biology 6, e309.

Van der Zee, R., Gómez-Moracho, T., Pisa, L., Sagastume, S. García- Palencia, P., Maside, X., Bartolomé, C., MartínHernández, R. and Higes, M. (2014). Virulence and polar tube protein genetic diversity of Nosema ceranae (Microsporidia) field isolates from Northern and Southern Europe in honeybees (Apis mellifera iberiensis). Environmental Microbiology Reports 6, 401-413.

Vávra, J. and Larsson, J.I. R. (2014). Structure of Microsporidia. In Microsporidia: Pathogens of Opportunity (ed. Weiss, L. M. and Becnel, J. J.), pp. 1-70. John Wiley \& Sons, Inc., Chichester.

Vavra, J. and Undeen, A. H. (1970). Nosema algerae n. sp. (Cnidospora, Microsporida) a Pathogen in a Laboratory Colony of Anopheles stephensi Liston (Diptera, Culicidae). Fournal of Protozoology 17, 240-249.

Vossbrinck, C. R., Baker, M.D., Didier, E.S., DebrunnerVossbrinck, B. A. and Shadduck, J. A. (1993). Ribosomal DNA sequences of Encephalitozoon hellem and Encephalitozoon cuniculi: species identification and phylogenetic construction. Fournal of Eukaryotic Microbiology 40, 354-362.

Vossbrinck, C. R., Andreadis, T. G. and Debrunner-Vossbrinck, B. A. (1998). Verification of intermediate hosts in the life cycles of Microsporidia by small subunit rDNA sequencing. Fournal of Eukaryotic Microbiology 45, 290-292.

Vossbrinck, C. R. and Debrunner-Vossbrinck, B. A. (2005). Molecular phylogeny of the Microsporidia: ecological, ultrastructural and taxonomic considerations. Folia Parasitogica 52, 131-142.

Wang, W. and Chen, J. (2007). Ultrastructural study on a novel microsporidian, Endoreticulatus eriocheir sp. nov. (Microsporidia, Encephalitozoonidae), parasite of Chinese mitten crab, Eriocheir sinensis (Crustacea, Decapoda). Fournal of Invertebrate Pathology 94, 77-83. 